\title{
The Video CAMERA SuRVEILlance (TEMPORARY MEASURES) ACT 2011: AN UNPRECEDENTED LICENCE TO SEARCH?
}

\section{Harriet Bush*}

This article examines the Video Camera Surveillance (Temporary Measures) Act 2011 which was passed as a result of the Supreme Court's decision in the case Hamed v R. This Act provided that a search was not unlawful simply because video surveillance was used. The article explores the previous court decisions on the lawfulness of police use of covert video surveillance in order to ascertain whether the premise upon which the Act was based, that video surveillance was lawful before Hamed v R, was correct. It then looks at the ratio decidendi of Hamed v R and the potential wider implications of this judgment. Finally, it assesses the state of the law under the Video Camera Surveillance (Temporary Measures) Act and whether this Act limited the right to be free from unreasonable search and seizure which is contained in 21 of the New Zealand Bill of Rights Act 1990.

\section{INTRODUCTION}

Within the last 20 years, the use of covert video surveillance has become a common police investigative technique in New Zealand and around the world. In 2011, for example, the New Zealand Police deployed an average of 47 cameras in 20 different operations each month. ${ }^{1}$ Despite the frequency with which this tool is now deployed, the legislature has been slow to regulate its use and, until recently, the appropriateness of deploying a camera in any given situation has been left largely to the discretion of the police. ${ }^{2}$ This has been made possible by the fact that despite several challenges to the lawfulness of the use of such surveillance, the courts have avoided answering the

* This article was submitted as part of the LLB(Hons) programme at Victoria University of Wellington. I would like to thank my supervisor, Professor Claudia Geiringer, for her invaluable guidance.

1 Justice and Electoral Committee Special Report Providing the Uncorrected Transcripts from the Hearings of Evidence on the Video Camera Surveillance (Temporary Measures) Bill (3 October 2011) at 74.

2 Law Commission Search and Surveillance Powers (NZLC R97, 2007) at [11.9] and [11.25]. 
question of whether video surveillance constitutes a "search" as the term is used in s 21 of the New Zealand Bill of Rights Act 1990 (NZBORA) and, if it does constitute a search, in what circumstances its use would be unreasonable. ${ }^{3}$

In September 2011, however, the Supreme Court of New Zealand addressed some aspects of the matter in Hamed $v R$ (Hamed). ${ }^{4}$ The majority of the Court found the use of video surveillance on private land unlawful and, in the circumstances of that case, an unreasonable search in breach of $\mathrm{s}$ 21 of NZBORA. ${ }^{5}$ The Crown claimed that this decision was a departure from the previous law on video surveillance. ${ }^{6}$ In response to this decision it immediately enacted the Video Camera Surveillance (Temporary Measures) Act 2011 (Temporary Act). This Act provided that a search would not be unlawful for the sole reason that video surveillance was used. ${ }^{7}$ The Act remained in place for six months until April 2012 when the Search and Surveillance Act 2012 was passed. ${ }^{8}$ This new Act revamped New Zealand's laws in relation to surveillance, providing a detailed warrant regime governing, and placing statutory limits on, the use of video surveillance. ${ }^{9}$

This article aims to examine and critique the Temporary Act. This Act is important because it demonstrates the action that the Crown is prepared to take in response to a decision of the Supreme Court with which it disagrees, and it sets a precedent for such reactive legislation in the future. The type of precedent that this legislation sets depends upon two key factors. The first is whether the reasons put forward by the Crown justifying legislative action represented a correct assessment of the legal position. The second is whether the act adequately fulfilled its purpose. Immediate legislative action was justified on the assertions that the use of covert video surveillance had been pronounced lawful to some extent prior to the decision in Hamed, that the decision in Hamed was a departure from this existing precedent and that this decision seriously limited the police's ability to use covert video surveillance during current and future investigations. The purpose of the temporary legislation was to allow the police to lawfully continue to use covert video surveillance without impinging on the right to be free from unreasonable search and seizure. If these assertions are

3 See $R v$ Fraser [1997] 2 NZLR 442 (CA) at 49; $R$ v Gardiner (1997) 15 CRNZ 131 (CA) at 134.

4 Hamed $v R$ [2011] NZSC 101, [2012] 2 NZLR 305.

5 At [51] per Elias CJ, [159] and [178] per Blanchard J, [227] per Tipping J, [263] per McGrath J and [281] per Gault J.

6 Video Camera Surveillance (Temporary Measures) Bill 2011 (333-1), cl 3(c); (27 September 2011) 676 NZPD 21425.

7 Christopher Finlayson "Video Camera Surveillance (Temporary Measures) Bill to be Introduced" (press release, 26 September 2011); Video Camera Surveillance (Temporary Measures) Act 2011, s 5(2).

8 Video Camera Surveillance (Temporary Measures) Act, s 5(1); Search and Surveillance Act 2012, s 2.

9 Search and Surveillance Act, ss 45-57. 
correct and the legislation fulfilled this purpose then the legislation can be seen as a relatively insignificant measure temporarily restoring important investigative powers to the police.

This article will first set out the necessary background information on covert video surveillance, the decision in Hamed and the key provisions of the Temporary Act. The second Part of the article will critique the justifications for the legislation by examining the precedent on the lawfulness of covert video surveillance in New Zealand. The third Part will assess the impact of the decision in Hamed. Finally, the article will look at the provisions of the Act itself and the extent to which the Act was consistent with s 21 of NZBORA.

This article will conclude that the Act was based upon an incorrect assessment of the previous state of the law on video surveillance and a misreading of the scope of the judgment in Hamed. The Act was poorly drafted and was both over and under-reaching. Ultimately the Act cannot be read as consistent with s 21 of NZBORA. It thus sets a worrying precedent for the enactment of knee-jerk legislation premised not only on an incorrect assessment of the legal position but which has serious implications for a fundamental protected right.

\section{BACKGROUND}

Before any critique of the Temporary Act is attempted, it is necessary to briefly examine the provisions of the legislation which show what it is that the Act purported to do. In order to provide the contextual information necessary for this legislation to be examined, this Part shall first define what is meant by covert video surveillance. Then, as the Act was a response to this decision, this Part shall briefly outline the facts of the Hamed decision. The decision itself shall be examined in more detail later in the article.

\section{A The Use of Covert Video Surveillance in Police Investigations}

Covert video surveillance refers to the use of a video camera for surveillance by law enforcement officers that is intended to be hidden from the view of those who are observed. ${ }^{10}$ In the context of this article, it refers to surveillance targeted at a particular individual or individuals as part of a police investigation. ${ }^{11}$ There are two types of covert video surveillance: trespassory and non-trespassory surveillance. Tresspassory surveillance occurs when the camera is situated on private land without the knowledge or consent of the occupier of that land. It is generally conducted as part of a search warranted by s 198 of the Summary Proceedings Act $1957 .{ }^{12}$ Non-trespassory

10 See for example Video Camera Surveillance (Temporary Measures) Act, s 5(1).

11 Indiscriminate public surveillance is beyond the scope of this article. For a discussion of the issues raised by this type of surveillance see Derek Lai "Public Video Surveillance by the State: Policy, Privacy Legislation and the Charter" (2007) 45 Alta L Rev 43; Jeremy Brown "Pan, Tilt, Zoom: Regulating the Use of Video Surveillance of Public Places" (2008) 23 Berkeley Tech L J 755.

12 See for example Video Camera Surveillance (Temporary Measures) Bill (333-2) (select committee report) at 1 . 
surveillance occurs when the camera is located on surrounding public land or on private land with the occupier's consent. ${ }^{13}$ This means that the use of trespassory and non-trespassory surveillance presents different issues. This is because trespassory surveillance involves police entry onto private land, which is unlawful unless specifically authorised, ${ }^{14}$ whereas non-trespassory surveillance does not.

\section{B Hamed v R: The Procedural Background}

The Hamed proceedings concerned charges laid against 19 defendants for the unlawful possession of a firearm under the Arms Act 1983. ${ }^{15}$ Four of the defendants were also charged with participation in a criminal group contrary to the Crimes Act $1961 .{ }^{16}$ These charges were laid after an 18-month police investigation into quasi-military style training camps held on private land in the Urewera Ranges. ${ }^{17}$ As part of this investigation the police had installed unmanned video cameras in different areas of that land for month-long periods. ${ }^{18}$ The Hamed proceedings were a pre-trial challenge to the admissibility of the evidence obtained through the police investigation. ${ }^{19}$ This article is focused on the challenge to the admissibility of the evidence obtained through the covert video surveillance only. In the High Court decision, reported as $R v$ Bailey, Winklemann $\mathrm{J}$ found that most of the video camera surveillance evidence was unlawfully obtained, however, she admitted the evidence under s 30 of the Evidence Act $2006 .{ }^{20}$ The defendants appealed this decision to the Court of Appeal. This was reported as Hunt v R (Hunt). ${ }^{21}$ The Court of Appeal found that the video surveillance was lawful. The defendants again appealed. In Hamed, the Supreme Court found that the police's use of trespassory surveillance amounted to a search under s 21 of NZBORA. ${ }^{22}$ As it was not authorised by any positive authority it was unlawful. ${ }^{23}$ It was also unreasonable, in breach of $\mathrm{s} 21 .^{24}$

13 At 2 .

14 Entick $v$ Carrington [1765] 95 ER 807 at 818.

15 Section 45(1)(b); Hamed $v$ R, above n 4, at [90]

16 Section 98A; Hamed $v$ R, above $\mathrm{n} 4$, at [90].

17 Hamed $v$ R, above n 4, at [92].

18 Hamed $v$ R, above n 4, at [93]-[107].

19 At [92].

$20 \quad R v$ Bailey HC Auckland CRI-2007-085-7843, 7 October 2009.

21 Hunt $v$ R [2010] NZCA 528, [2011] 2 NZLR 499.

22 At [8] per Elias CJ, [171] per Blanchard J and [227] per Tipping J.

23 At [159] per Blanchard J, [227] per Tipping J and [281] per Gault J.

24 At [51] per Elias CJ, [178] per Blanchard J, [227] per Tipping J, [263] per McGrath J and [281] per Gault J. 


\section{The Provisions of the Video Camera Surveillance (Temporary Measures) Act 2011}

The Temporary Act was passed in October 2011 in response to the decision in Hamed. ${ }^{25}$ The Act's main operative provision was s 5 . It ensured the "temporary continuation of lawfulness of certain uses of video camera surveillance" by providing that "the use of covert video surveillance as part of, or in connection with, a search does not of itself render the search unlawful". "Search" is defined in $\mathrm{s} 4$ of the Act as:

an act done by a person or body referred to in section 3(b) of the New Zealand Bill of Rights Act 1990

(a) that is, or is in connection with, a search in respect of which a search warrant has been issued; or

(b) that is a search where surveillance is conducted from outside the boundaries of the land or place under observation.

Subsection (a) refers to trespassory video surveillance, undertaken in conjunction with a search under a s 198 search warrant. Subsection (b) refers to surveillance from outside a property, that is, non-trespassory surveillance. This means that the Act encompasses both trespassory surveillance and non-trespassory surveillance.

The aims of the legislation are listed in the purpose section. ${ }^{26}$ The most important of these purposes are:

(b) to provide a temporary period that will enable Parliament to address in a comprehensive way the matters raised in the decision regarding the lawful and appropriate use of video camera surveillance as part of law enforcement; and

(c) to uphold ... the deployment of video camera surveillance only to the extent that it was considered to be not unlawful in decisions prior to the decision in Hamed; and

(d) to ensure that the right to be secure against unreasonable search and seizure set out in section 21 of the New Zealand Bill of Rights Act 1990 is unaffected by the temporary measures put in place by this Act (emphasis added.)

This purpose section reflects the assertions upon which the Bill was premised. The first was the assumption that covert video surveillance was considered "not unlawful" to some extent prior to Hamed. Politicians claimed that the court had previously examined the use of covert video surveillance and found that it was lawful whether "it was conducted on private property entered into

25 Video Camera Surveillance (Temporary Measures) Act, s 2.

26 Section 3. 
pursuant to a search warrant or from a place not requiring a warrant to enter." 27 That is, the Crown claimed that both trespassory and non-trespassory surveillance were previously lawful. The second important assertion reflected in the purpose section is that the Bill would not limit the right to be free from unreasonable search and seizure.

\section{PREVIOUS AUTHORITY CONCERNING THE LAWFULNESS OF COVERT VIDEO SURVEILLANCE}

The lawfulness of police use of both trespassory and non-trespassory covert video surveillance had been challenged in various cases before the courts prior to the matter arising in the Hamed proceedings. These challenges to the use of covert video surveillance had been based upon the argument that covert video surveillance constitutes a search within the meaning of the word as used in s 21 of NZBORA and that its use, without positive authority, is an unreasonable search in breach of that section. ${ }^{28}$

Section 21 of NZBORA provides that:

Everyone has the right to be secure against unreasonable search or seizure, whether of the person, property, or correspondence or otherwise.

The courts have taken a two-step approach to this section, first looking at whether the activity was a search and secondly at whether the search was unreasonable. ${ }^{29}$ The Supreme Court has found that once this section is breached there is no role for s 5 of NZBORA: an unreasonable search cannot be demonstrably justified in a free and democratic society. ${ }^{30}$

This Part of the article will assess the success of this argument in relation first to nontrespassory and then to trespassory surveillance by looking at the key New Zealand decisions concerning video surveillance. This assessment will provide the answer to whether the first assertion upon which the Temporary Act was based - that covert video surveillance was lawful to some extent prior to Hamed - was accurate.

\section{A Prior to the Hamed Proceedings, Had the Use of Non-Trespassory Video Surveillance Been Found Lawful?}

The Court of Appeal had considered police use of non-trespassory covert video surveillance in two key decisions before the Supreme Court's decision in Hamed: $R v$ Fraser (Fraser) ${ }^{31}$ and $R v$

27 Video Camera Surveillance (Temporary Measures) Bill (333-2) (select committee report) at 1.

$28 R v$ Fraser, above n 3; $R v$ Gardiner, above $\mathrm{n} 3 ;$ Hamed $v R$, above $\mathrm{n} 4$.

29 See Hamed $v$ R, above n 4, at [162]; $R$ v Fraser, above n 3, at 449; $R v$ Gardiner, above $\mathrm{n} 3$, at 137.

30 Hamed v R, above n 4, at [187]; Cropp v Judicial Committee [2008] NZSC 46, [2008] 3 NZLR 774 at [33].

$31 \quad R v$ Fraser, above $\mathrm{n} 3$. 
Gardiner (Gardiner). ${ }^{32}$ In both of these cases a camera was set up outside of the private property under surveillance. ${ }^{33}$ In both cases the Court refused to identify whether the surveillance amounted to a search within the meaning of $\mathrm{s} 21 .{ }^{34}$

Fraser concerned a challenge to the admissibility of evidence obtained through non-trespassory video surveillance of a defendant charged under the Misuse of Drugs Act 1975. In this case the Court said that the touchstone of s 21 was the protection of privacy. However, it held that there was no consistent approach as to whether reasonable expectations of privacy were part of the initial test for whether a search had occurred, or whether they were only relevant to assessing whether the search was reasonable. ${ }^{35}$ While the Court noted that the White Paper proposal which gave rise to NZBORA said that s 21 should extend to new forms of intrusive technologies, ${ }^{36}$ it felt that nontrespassory surveillance, which involved no entry onto the premises, presented particularly difficult issues in relation to that section. ${ }^{37}$ For this reason the Court considered that it would be better for it to have considered more cases before it attempted to define the elements of search and seizure. ${ }^{38}$ Therefore, instead of deciding whether or not the surveillance constituted a search, the Court simply looked at whether the activity, if it amounted to a search, was reasonable. ${ }^{39}$ As s 21 only protects against unreasonable searches, in cases where the activity is reasonable, the section will not be breached even if it is deemed that there has been a search.

The Court of Appeal also took this approach in assessing the police behaviour in Gardiner $^{40}$ and in several cases concerning audio electronic participant surveillance ${ }^{41}$ and telephone number taping. ${ }^{42}$ In all of these cases the activity was found to be reasonable, ${ }^{43}$ with the result that the Court was never forced to articulate a test for what constitutes a search under s 21 .

$32 R v$ Gardiner, above $\mathrm{n} 3$

$33 R v$ Fraser, above n 3, at 445; $R$ v Gardiner, above n 3, at 133.

$34 \quad R v$ Fraser, above n 3, at 452.

35 At 449

36 Geoffrey Palmer "A Bill of Rights for New Zealand: A White Paper" [1984-1985] I AJHR A6 at [10.152].

37 At 449 .

38 At 449

39 At 452 .

40 At 134

$41 \quad R v$ Barlow (1995) 2 HRNZ 635 (CA).

$42 \quad R v$ Wong-Tung (1995) 2 HRNZ 272 (CA).

$43 \quad R v$ Fraser, above $\mathrm{n} 3$, at 453; $R$ v Gardiner, above $\mathrm{n} 3$, at 137; $R v$ Wong-Tung, above $\mathrm{n} 42$, at $274 ; R v$ Barlow, above n 41, at 667 . 
Having assumed, for the sake of argument, that video surveillance was a search, the Court in Fraser and Gardiner then considered whether undertaking non-trespassory covert video surveillance was lawful. It first addressed whether there was any statutory authority for the surveillance. Counsel argued that s 198 of the Summary Proceedings Act 1957 provided a basis for undertaking surveillance. ${ }^{44}$ The relevant part of this section permits a search warrant to be granted where there are "reasonable grounds" to believe that there is any "thing" on a place or premises which has been or will be used in the commission of an offence, or will be evidence of such an offence. ${ }^{45}$ The Court said that the section was directed at entry into a property to search for "things". It did not think that it could be interpreted so as to authorise observations from remote places outside of a property. ${ }^{46}$

However, the Court rejected the argument put forward by the defendants that, in the absence of statutory authority, it was unlawful to carry out surveillance. In Fraser the Court said: ${ }^{47}$

Other than s 21 of the New Zealand Bill of Rights Act, Counsel did not point to any statutory or common law prohibition against observing or recording on videotape the open air surrounding a residential property and plainly there is none.

This statement recognises what has been termed the third source of authority for government actions. ${ }^{48}$ This doctrine supports a residual freedom for the police to do things in the course of their enquiries which are not prohibited by law. ${ }^{49}$ That is, the police do not need to point to positive authority to allow them do something which would be lawful for an individual to do. ${ }^{50}$ As there is nothing unlawful in setting up a camera on public land, the police do not need authorisation to do so. More recently, this approach to police action was applied by Tipping and McGrath JJ in their decisions in $R v N g a n .^{51}$

In Gardiner, the argument was also raised as to whether, despite the requirements at common law, NZBORA meant that there must be prior authorisation for a search. ${ }^{52}$ This argument was based upon that accepted by the European Court of Human Rights (ECtHR) in Malone $v$ United

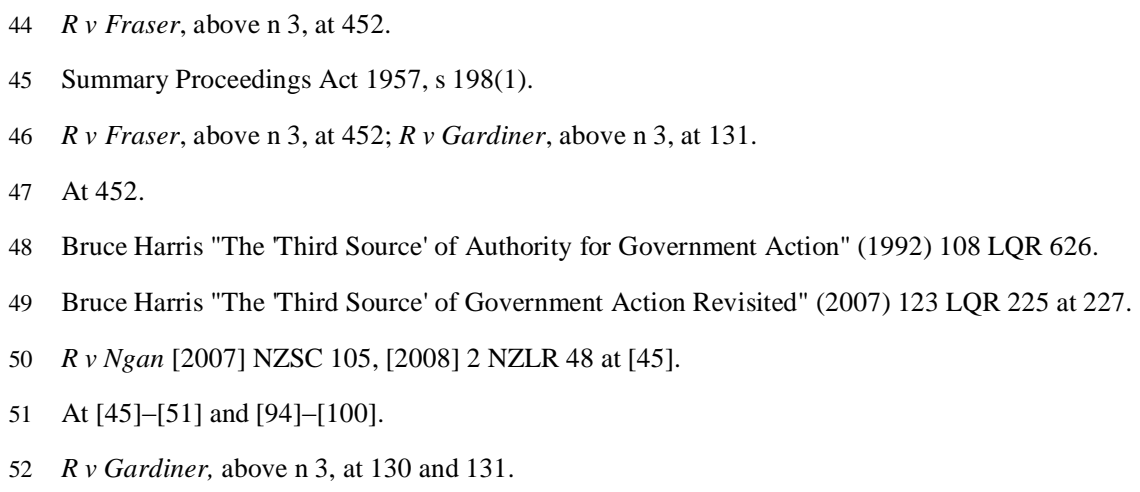


Kingdom. ${ }^{53}$ It is also the approach taken in Canada ${ }^{54}$ and the United States. ${ }^{55}$ In these countries, prior judicial authorisation is a prerequisite for a search to be reasonable under the relevant human rights legislation. This argument would mean that the doctrine of the third source could not apply to warrantless surveillance, as to undertake such surveillance would amount to an unreasonable search in contravention of an existing right and would be unlawful. As McGrath J recognised in $R v$ Ngan, the third source doctrine can never justify a breach of protected rights. ${ }^{56}$ However, the Court in Gardiner rejected this argument. The Court said that it did not think that NZBORA had had the effect to render video surveillance, which was otherwise ungoverned by domestic law, unlawful. ${ }^{57}$

This means that following these two cases, undertaking non-trespassory video surveillance without statutory authority is lawful at common law. Further, a warrant is not a prerequisite for reasonableness under s 21 .

The next question when assessing compliance with s 21 of NZBORA is whether a lawful search can nevertheless be unreasonable. In $R v$ Williams the Court of Appeal said that a lawful search will not normally be unreasonable. ${ }^{58}$ However, this statement was made in the context of a search authorised by statute. The statute provides safeguards on searches through the warrant regime. A warranted search has met certain criteria, which is in effect a check that it is reasonable. In comparison, non-trespassory surveillance is lawful in the absence of any warrant regime. Consequently, the reasoning that the search will not normally be unreasonable because it is lawful does not automatically apply.

A lawful search might become unreasonable if carried out in an unreasonable manner. ${ }^{59}$ For example, in $R v$ Pratt a lawful strip search was held to be unreasonable because it was carried out in public with disregard for the dignity of the person and the time and place it occurred ${ }^{60}$ In the context of non-trespassory surveillance, Fraser and Gardiner made it clear that the lawfulness of the search is not the end of the matter when looking at its reasonableness. In Fraser the Court said that when assessing the reasonableness of a search it was necessary to have regard to the circumstances at the time of the search and balance the legitimate interests of the individual by reference to

53 Malone v United Kingdom (1984) 7 EHRR 14

54 See $R v$ Collins [1987] 1 SCR 265 at 278; Hunter $v$ Southam [1984] 2 SCR 145 at [29]; $R v$ Wong [1990] 3 SCR 36 at [20]-[27].

55 See United States v Falls 34 F 3d 674 (8th Cir 1994); United States v Taketa 923 F 2d 665 (9th Cir 1991).

$56 R v N g a n$, above n 50, at [97].

$57 \quad R v$ Gardiner, above $\mathrm{n} 3$, at 134

$58 \quad R v$ Williams [2007] NZCA 52, [2007] 3 NZLR 207 at [24].

$59 R v$ Williams, above n 58, at [24].

$60 \quad R v$ Pratt [1994] 3 NZLR 21 (CA) at 23. 
reasonable expectations of privacy against the interests of the State in the detection and prosecution of crime. ${ }^{61}$ The Court noted that reasonable expectations of privacy would be less for activities readily visible from outside the property than activities within buildings. It concluded that in this case there was no evidence that the appellant could have expected that he wouldn't be observed in the area upon which the camera was focused. Therefore, it found that the non-trespassory video surveillance was not unreasonable. ${ }^{62}$

In Gardiner the camera was focused on the back door, kitchen and dining room windows of the appellant's house. ${ }^{63}$ The Court said that covert video surveillance encompassing the interior of a building would not normally be reasonable. ${ }^{64}$ However in this case, the appellants were taking precautions against audio interception, the police had strong grounds for suspecting an offence was taking place and the camera was not trained on an area of particular privacy. Therefore, the Court found that the surveillance was not unreasonable. ${ }^{65}$

These two cases show that before the decision in Hamed, the Court had found that nontrespassory covert video surveillance was lawful despite the lack of a statutory basis for its use. The Court had yet to decide whether, and in what circumstances, its use was a search under s 21 . However, if the Court did find that it amounted to a search then it would be subject to a case-bycase assessment of reasonableness based on the time, place and circumstances in which it was undertaken. Fraser and Gardiner are two examples of situations where the Court considered that the use of non-trespassory surveillance was reasonable in the circumstances. These cases do not stand for the proposition that non-trespassory surveillance will always be allowed. For example in Gardiner the Court explicitly stated that surveillance of the interior of a building was likely to be unreasonable.

\title{
B Prior to the Hamed Proceedings, Had the Use of Trespassory Covert Video Surveillance Been Found Lawful?
}

The use of trespassory surveillance had come before the courts prior to Hamed in a variety of different cases. In an early decision, $R v$ Grayson and Taylor, the Court of Appeal was asked to assess the reasonableness of police actions under a search warrant. The police officers had

\author{
61 At 453 . \\ 62 At 453 . \\ $63 R v$ Gardiner, above n 3, at 133. \\ 64 At 136. \\ 65 At $136-137$
}


undertaken video recording while on the suspect's property. ${ }^{66}$ Despite counsel drawing this to the Court's attention, ${ }^{67}$ its use was not the subject of any separate analysis by the Court. ${ }^{68}$

In 2007, the Law Commission released a detailed report into New Zealand's search and surveillance laws. This questioned the legal basis for trespassory surveillance. ${ }^{69}$ The Select Committee that examined the Video Camera Surveillance Bill noted that this was the case; however, it argued that this report was released before three Court of Appeal decisions affirmed the lawfulness of trespassory surveillance. ${ }^{70}$ The decisions referred to were presumably Tararo $v R$ (Tararo), ${ }^{71}$ Hodgkinson v R (Hodgkinson) ${ }^{72}$ and Hunt. ${ }^{73}$

In Tararo the Supreme Court addressed the use of a video camera by a police officer. In this case the undercover police officer had entered onto private property to purchase cannabis. $\mathrm{He}$ approached the house and transacted with the man who came to the door. This transaction was recorded by a video camera concealed on the officer. ${ }^{74}$ In the Court of Appeal the Court indicated that it thought that such surveillance amounted to a search, but it did not decide the case on this footing. ${ }^{75}$ The Supreme Court did not address this matter. The Supreme Court accepted the argument that the police officer had entered the land pursuant to the common law implied licence to make an enquiry of the occupier. ${ }^{76}$ The Court said that this implied licence also allowed a police officer to take photographs where this was done to make a record to support the police officer's evidence of what he had done or seen on the premises. ${ }^{77}$ The Court endorsed the view previously taken by the Court of Appeal in $R v$ Barlow $^{78}$ that participant recording would not be inherently

$66 \quad R v$ Grayson and Taylor [1997] 1 NZLR 399 (CA) at 408.

67 Andrew Butler "The End of Precedent in Bill of Rights Cases? A note on $R v$ Grayson" [1997] NZ L Rev 274 at 283 .

$68 R v$ Grayson and Taylor, above $\mathrm{n} 66$, at 408.

69 Law Commission, above $\mathrm{n} 2$.

70 Video Camera Surveillance (Temporary Measures) Bill (333-2) (select committee report) at 2.

71 Tararo $v R$ [2010] NZSC 157, [2012] 1 NZLR 145.

72 Hodgkinson $v$ R [2010] NZCA 457.

73 Hunt $v$ R, above $\mathrm{n} 21$.

74 Tararo $v$, above $\mathrm{n} 71$, at [5] and [6].

75 At [64].

76 At [14].

77 At [14].

$78 R v$ Barlow, above n 41. 
unreasonable or overstep the boundary of an implied licence where its purpose was to obtain a full and accurate record of what was heard or seen. ${ }^{79}$

It is important that this judgment is understood in the context of its particular facts and not extended to other uses of covert video surveillance. Tararo concerned surveillance being used to provide a record of what an officer saw. This is different from an unmanned camera used to record what occurs on the land for long stretches of time when the occupants think that they are unobserved. In Tararo, entry onto the property was justified under an implied licence to speak to the occupier. In contrast the purpose of a s 198 warrant, in conjunction with which most covert video surveillance is undertaken, is not to allow the police to speak to an occupier, but to search for evidence.

The next relevant Court of Appeal decision concerning trespassory surveillance was Hodgkinson. The appellants in this case were charged with cultivation, supply and possession of cannabis for supply under the Misuse of Drugs Act $1975 .{ }^{80}$ The District Court had ruled that all of the evidence obtained by the police under a series of search warrants was admissible against the appellants. ${ }^{81}$ One of the warrants was sought by the police to authorise covert trespassory video surveillance of private property. This warrant was granted, although it did not in its terms authorise the surveillance. ${ }^{82}$ The District Court judge held that this warrant was improperly issued and the material seized under it was seized improperly. However, he ruled the evidence admissible under s 30 of the Evidence Act $2006 .{ }^{83}$ The appellants appealed against this finding on the ground that the evidence obtained under this warrant should have been excluded. ${ }^{84}$ The Hodgkinson proceedings were brought after the High Court decision in the Hamed proceedings but before the Court of Appeal decision. In the High Court decision, $R v$ Bailey, Winkelmann $\mathrm{J}$ had found that a $\mathrm{s} 198$ warrant could not authorise covert video surveillance. ${ }^{85}$ In light of this decision, the Crown in Hodgkinson conceded that the video surveillance was not authorised by the warrant and was unlawful. ${ }^{86}$ However, the Court of Appeal said that it considered it "strongly arguable" that a warrant could authorise surveillance. ${ }^{87}$ Despite this, the Court acknowledged that there was doubt as

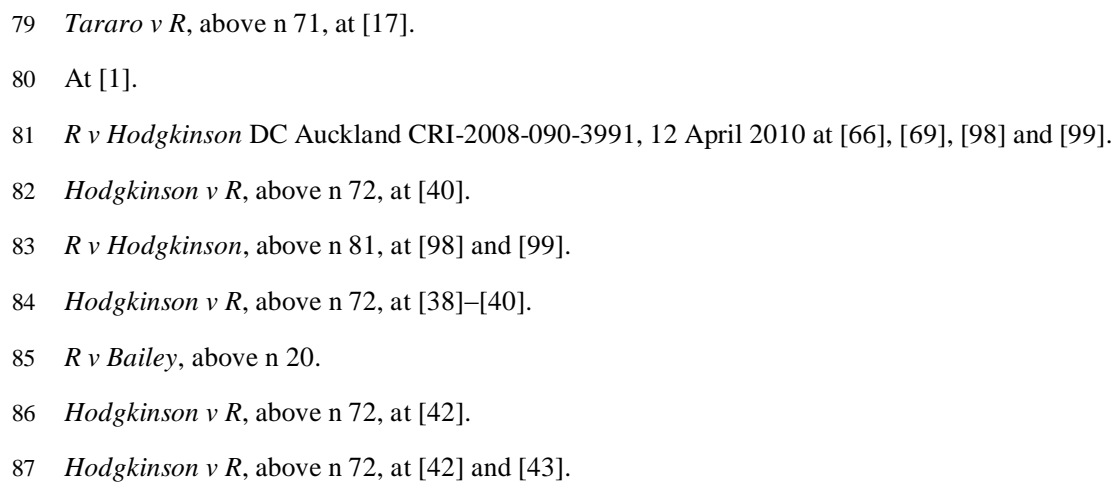


to whether a s 198 warrant could authorise surveillance and, in light of the Crown's concession that the surveillance was not authorised, the Court proceeded on the assumption that the surveillance was not authorised by the warrant and was therefore unlawful. ${ }^{88}$ This meant that the Court did not need to address the issue of whether the surveillance amounted to a search within the meaning of $\mathrm{s} 21$ of NZBORA, ${ }^{89}$ and decided the case on whether the surveillance evidence should have been excluded under $\mathrm{s} 30$ of the Evidence Act. ${ }^{90}$

The final relevant Court of Appeal decision concerning trespassory video surveillance was its decision in the Hamed proceeding itself, Hunt. The Court found that the trespassory surveillance undertaken by the police had been authorised by the s 198 warrants. The Court held that provided that the use of covert surveillance related to "things" of evidential significance, it was justifiable under a warrant. ${ }^{91}$ The Court said that an intention to conduct surveillance should be disclosed in the warrant application. It noted that while it was difficult to envisage circumstances where surveillance of a bedroom was justified, if the police could look personally when carrying out a search there was no reason in principle why they could not carry out the same sort of surveillance by video. ${ }^{92}$ This decision was of course overturned several months later on appeal to the Supreme Court which found that it was incorrect. ${ }^{93}$

Neither Hodgkinson nor Tararo support the proposition that trespassory video camera surveillance was lawful prior to Hamed. In Hodgkinson the Court simply said that it considered that it was arguable that such surveillance could be authorised by a s 198 warrant. It is important to remember that this decision came after the police activity in the Hamed proceedings had taken place, and consequently cannot be relied upon to justify the police actions in this investigation. Neither can it be used to show a long-standing legal position on the legality of covert surveillance. The decision in Tararo is confined to the much narrower issue of participant surveillance simply being used to provide a record of what the police officer saw when entering under the common law doctrine of an implied licence. This means that Hunt is the only Court of Appeal decision that has found the use of trespassory surveillance lawful. However, the Select Committee and supporters of the Bill relied on these cases to argue that the legal basis of trespassory surveillance had been affirmed by the Court of Appeal. This is misleading. $R v$ Bailey found that trespassory surveillance

88 Hodgkinson $v$ R, above $\mathrm{n} 72$, at [45].

89 The Court did, however, think that the concept of search in s 198 was wide enough to include surveillance: at [42]. This concept is narrower than the term as used in s 21 (see Hamed $v$, above $\mathrm{n} 4$, at [164]), so it seems likely that it would consider surveillance a search for the purposes of $\mathrm{s} 21$.

90 Hodgkinson $v R$, above $\mathrm{n} 72$, at [46]-[54].

91 At [37].

92 At [41]-[42].

93 Hamed $v$ R, above n 4, at [6], [149], [210], [263] and [281]. 
was unlawful. Hodgkinson noted that there were arguments either way. In this context, one Court of Appeal decision that trespassory surveillance was lawful was not enough to establish a settled legal position on the legality of trespassory surveillance from which the Supreme Court's judgment departed.

\section{Conclusion on the Legality of the Use of Covert Video Surveillance Prior to the Decision in Hamed}

This examination of previous case law has shown that the assertion that covert video surveillance was lawful prior to the decision in Hamed was incorrect. Although non-trespassory surveillance was lawful in certain circumstances, prior to the start of the Hamed proceedings it was uncertain at best as to whether trespassory surveillance was lawful.

\section{THE EFFECT OF THE DECISION IN HAMED ON THE CONTINUED USE OF VIDEO CAMERA SURVEILLANCE}

Throughout the Video Camera Surveillance Bill's passage through Parliament, it was claimed that the decision in Hamed represented a departure from the previous authority on covert video surveillance. ${ }^{94}$ Further, the Government stated that Hamed had the following effect: ${ }^{95}$

a. The use of covert video surveillance as part of the exercise of a search warrant was unlawful

b. Non-trespassory surveillance was also likely to be held to be unlawful

c. If covert video surveillance was unlawful, it was likely to be found to be unreasonable and in breach

of section 21 of the NZBORA.

This Part of the article will look at the accuracy of each of these propositions in turn to assess the impact of Hamed on the ability of the police to lawfully use trespassory and non-trespassory video surveillance as an investigative tool.

\section{A Post Hamed, Was the Use of Trespassory Video Camera Surveillance Unlawful?}

Hamed found that the use of trespassory surveillance was not authorised by warrant and was unlawful. ${ }^{96}$ In order to reach this conclusion, the Court stated for the first time that the use of

94 Crown Law Office Crown Law Report, Justice and Electoral Select Committee: Video Camera Surveillance (Temporary Measures) Bill (29 September 2011) at [9].

95 Video Camera Surveillance (Temporary Measures) Bill (333-1) (explanatory note). See also Crown Law Office, above n 94, at [49.8].

96 Hamed $v$ R, above n 4, at [51], [159], [178], [227], [263] and [281]. 
trespassory surveillance in certain circumstances would amount to a search in terms of s 21 of NZBORA. ${ }^{97}$ However, their Honours put forward different tests as to what constitutes a search.

Blanchard J took a narrow view of "search" and said that a search only occurred when the activity invaded a reasonable expectation of privacy. ${ }^{98}$ This is broadly similar to Elias CJ's approach. Her Honour said that s 21 protected privacy and that an activity would be a search when it invaded the right to individual freedom from intrusion by the state. ${ }^{99}$ While Blanchard $\mathbf{J}$ said that video surveillance in a public space would not normally amount to a search unless perhaps it involved vision enhancing devices, Elias CJ said that there was no reason why, by that reason alone, surveillance of a public space should be outside the scope of s $21 .{ }^{100}$

Tipping J, on the other hand, said that reasonable expectations of privacy should be confined to the assessment of reasonableness once a search had been established. He believed that a search could occur without any reasonable expectation of privacy being breached. ${ }^{101}$ Tipping $\mathrm{J}$ said that the word "search" in s 21 had the ordinary meaning of consciously looking for something or someone. It was therefore wide enough to cover watching people or places by the use of technological devices. ${ }^{102}$

These two contracting approaches to what constitutes a search both have some support in previous cases. ${ }^{103}$ However, while McGrath J did not make it clear whether he agreed with Tipping or Blanchard JJ's approach to the test for a search, ${ }^{104}$ Gault J said that he agreed with Blanchard J's reasoning. ${ }^{105}$ Elias CJ and Blanchard Js' tests are not exactly the same, but their approaches are broadly similar. This led the Court of Appeal in Lorigan $v R$ to conclude that while there was no clear majority on the matter it was Blanchard J's judgment which had the majority support. ${ }^{106}$

97 At [8], [171], [221], [265] and [281]. However, Blanchard J took the approach that in this case the surveillance of vehicles along Reid Road was not a search as there was not a high expectation of privacy: at [171].

98 At [163].

99 At [10].

100 Compare Elias CJ at [12] and Blanchard J at [167].

101 At [223].

102 At [220].

103 Compare for example $R v$ Grayson and Taylor, above $\mathrm{n} 66$, at 406 and $R v N g a n$, above $\mathrm{n} 50$, at [111].

104 At [265].

105 At [281].

106 Lorigan $v R$ [2012] NZCA 264, (2012) 25 CRNZ 729 at [22]. The Court reached this decision by looking at the approaches that Gault and McGrath JJ had taken in previous cases involving video surveillance. In this case the Court found that non-trespassory surveillance of a public space is not generally a search, however, 
Once their Honours had decided that the video camera surveillance was a search, they went on to assess whether there was any authority for it. The Court said that the surveillance would be unlawful unless it was justified by an implied licence to enter the property, as in Tararo, or by a statutory provision. ${ }^{107}$ The Court rejected the argument that the surveillance could be justified by an implied licence for the reason that the police officers were not on the land to communicate with the occupiers. ${ }^{108}$ The Court also rejected the argument that the surveillance could be authorised by a $\mathrm{s}$ 198 search warrant. ${ }^{109}$ Their Honours said that this was because the section was restricted to authorising entry to search for things which were believed to be on the property at the time the warrant was applied for. ${ }^{110}$ Video surveillance did not come within this section because it was prospective in nature. Further, its use could not properly be regarded as a search for "things". Its purpose was to search for people in relation to those things. ${ }^{111}$ As the warrant did not extend to surveillance, this meant that when the police undertook the surveillance they overstepped the authority of the warrant and were trespassing. This being the case, the surveillance was unlawful. ${ }^{112}$

Following the decision in Hamed, the use of trespassory surveillance as part of a search warrant was therefore unlawful.

\section{B Post Hamed, Was the Use of Non-Trespassory Covert Video Surveillance Likely to be Held to be Unlawful?}

The Crown's reading of the decision in Hamed was that it could be interpreted by future courts in such a way that police would be required to have a warrant for non-trespassory surveillance to be lawful. ${ }^{113}$ Due to the different approaches taken by Elias CJ, Blanchard and Tipping JJ this proposition has to be carefully examined. Its accuracy depends upon whether the judgments are read as extending to non-trespassory surveillance or confined to trespassory surveillance.

In his judgment Tipping $\mathrm{J}$ said that he endorsed the view taken in $R v$ Ngan and considered that the police were entitled to do anything which any member of the public would be able to do in the same circumstances. ${ }^{114}$ As it would be lawful for a private citizen to set up a camera on public

surveillance using a camera with night-filming capacity would involve a search as this allowed it to film images not visible to the naked eye.

107 Hamed $v$ R, above $\mathrm{n}$ 4, at [161], [219] and [281].

108 At [161], [219] and [281].

109 At [47], [149], [210] and [281].

110 At [146].

111 At [150] per Blanchard J and [209] per Tipping J.

112 At [175].

113 Crown Law Office, above n 94, at [9] and [49].

114 Hamed $v$ R, above $\mathrm{n} 4$, at [217]. 
property, ${ }^{115}$ Tipping J's remarks about the lawfulness of the search are clearly confined to trespassory surveillance.

Elias CJ took the opposite approach and held that the police act unlawfully when they do not have specific statutory authority for intruding upon personal freedoms. Specific authority, her Honour said, is required both at common law and under NZBORA. ${ }^{116}$ This means that once surveillance amounts to a search within the meaning of s 21 , it must be authorised by statute to be lawful. Following Elias CJ's approach, both trespassory and non-trespassory surveillance are unlawful unless authorised by warrant.

While the scope of Elias CJ and Tipping J's judgments are clear, Blanchard J's judgment is somewhat more ambiguous. It is Blanchard J's approach which has created disagreement as to the potential wider application of the decision in Hamed. This disagreement has been based upon the interpretation of one particular passage in Blanchard J's judgment where he said:117

In this case the video camera surveillance was not authorised by any warrant. Even in the instances

when the police had a valid warrant to enter the land concerned, they still had no right to carry out the

surveillance and were trespassing when they installed video cameras.

There are two possible ways to interpret this statement. Taking a narrow approach, this statement is confined to trespassory surveillance: the video surveillance was beyond the scope of the warrant and so by undertaking it, the police officers overstepped their authority and became trespassers. ${ }^{118}$ However, a broader reading of the statement could interpret Blanchard $\mathbf{J}$ as simply saying that there was no law that gave the police officers the "right" to undertake the trespassory surveillance. There is similarly no law which gives the police officers the "right" to undertake nontrespassory surveillance, so the same reasoning would apply to non-trespassory surveillance and it would also be unlawful. ${ }^{119}$

In Lorigan $v R$, the Court of Appeal said that it considered Tipping J's approach towards police powers to have the support of the majority of the judges. ${ }^{120}$ This means that it understood Blanchard J's judgment as consistent with Tipping J's and read Blanchard J's above remark about warrants as confined to trespassory surveillance.

115 There are several minor exceptions to this general position, for example "peeping and peering" into a dwellinghouse at night: see Law Commission, above n 2, at [11.19] and [11.20]

116 Hamed $v$ R, above $\mathrm{n} 4$, at [38].

117 At [175].

118 Crown Law Office, above n 94, at [45].

119 At [9].

120 Lorigan $v R$, above 106, at [30]. 
A narrow reading of Blanchard J's judgment was also supported by submitters on the Video Surveillance Bill. For example, Andrew Geddis took the view that nothing in the majority judgments in Hamed could be read as saying that the police must have specific authority in law to undertake non-trespassory surveillance. ${ }^{121}$

This approach to the passage of Blanchard J's judgment quoted above seems correct in the wider context of Blanchard J's judgment and those of the other Justices. Elias CJ was emphatic in her rejection of the reasoning in both Fraser and Gardiner. ${ }^{122}$ In contrast, Blanchard J referred briefly to Fraser in the context of the test for a reasonable search. ${ }^{123}$ In Fraser, the Court found that there was no need for statutory authorisation for non-trespassory surveillance to be lawful. Given this context, it would be odd if Blanchard $\mathbf{J}$ intended the somewhat ambiguous language in the above paragraph to be seen as disagreeing with the fundamental reasoning behind that case - that prior authorisation for non-trespassory surveillance was not a prerequisite for its use to be reasonable.

In conclusion, the correct reading of Hamed is that the majority's comments on the need for specific authorisation for a search are confined to trespassory surveillance. This means that following Hamed, non-trespassory surveillance was not likely to be found to be unlawful, unless it was unreasonable.

\section{If the Use of Covert Video Surveillance Was Unlawful, Was it Likely to be Found to be Unreasonable?}

The final proposition in the Bill's explanatory note was that given that covert video surveillance had been found to be unlawful, it was also likely to be held unreasonable. Due to the finding on the previous point, this proposition is only relevant to trespassory surveillance.

There has been considerable disagreement over the proper relationship between the lawfulness and the reasonableness of a search. In Hamed, Elias CJ, Blanchard and Tipping JJ took different approaches to this relationship.

With the exception of Elias CJ, all the Justices said that unlawfulness and unreasonableness were distinct concepts. ${ }^{124}$ Blanchard J said that normally a search would be unreasonable where it was established that it was unlawful, however, an exception would be where the unlawfulness was

121 Andrew Geddis "Submission to the Justice and Electoral Committee on the Video Camera Surveillance (Temporary Measures) Bill 2011" at [4].

122 Hamed $v$ R, above n 4, at [32].

123 At [163].

124 At [174] per Blanchard J and [226] per Tipping J. McGrath J said that he agreed that unlawfulness and unreasonableness were distinct concepts, at [263]. Gault J said that he agreed with Blanchard J's reasoning, at [281]. 
minor or technical or perhaps where the police had a reasonable but erroneous belief that they were acting lawfully. ${ }^{125}$

Blanchard J's approach is consistent with the approach taken to the relationship between lawfulness and reasonableness since $R v$ Shaheed. ${ }^{126}$ Prior to this decision, the Court said that the time, place and circumstances of the search should be assessed to establish whether or not the search was reasonable. ${ }^{127}$ This had allowed the courts to assess the reasonableness of a search independently of its unlawfulness. However, in $R v$ Shaheed the Court acknowledged that this approach was inappropriate, was not based on principle, and was a result of the prima facie exclusion of evidence rule. ${ }^{128}$ This rule meant that evidence obtained in breach of s 21 would be excluded unless there was good reason to admit it. ${ }^{129}$ Courts were therefore reluctant to say that $\mathrm{s} 21$ had been breached, as the likely result of such a finding was that the evidence would be excluded. ${ }^{130}$ Following the replacement of this rule in Shaheed with a balancing test, ${ }^{131}$ the Court has found a closer relationship between unlawfulness and unreasonableness. Thus in $R v$ Williams the Court said that an unlawful search would ordinarily be unreasonable, ${ }^{132}$ with the possible exception of when the unlawfulness was due to a minor or technical error. ${ }^{133}$ This exception meant that there was no risk of trivialising the s 21 right by the section being breached on a technicality. ${ }^{134}$

Tipping J's approach in Hamed to unlawfulness and unreasonableness was similar to Blanchard J's. His Honour said that an unlawful search was well on the way towards being unreasonable: ${ }^{135}$

A party propounding the view that [an unlawful search] was nevertheless not unreasonable carries a significant persuasive burden, but that is not to say that the burden can never be satisfied.

However, the wording of this statement is more flexible than that found in Blanchard J's judgment and could possibly be used to argue that an unlawful search was reasonable in circumstances outside of those exceptions noted by Blanchard $\mathbf{J}$ and the previous cases. Despite this,

125 At [174].

$126 R v$ Shaheed [2002] 2 NZLR 377 (CA); $R v$ Williams, above $\mathrm{n} 58$, at [16]-[20].

$127 R v$ Grayson and Taylor, above $\mathrm{n} 66$, at 407.

$128 R$ Shaheed, above n 126, at [144]; Hamed $v$ R, above n 4, at [173].

$129 R v$ Shaheed, above $\mathrm{n} 126$, at [144]. See also $R v$ Williams, above $\mathrm{n} 58$, at [14].

130 Hamed $v R$, above $\mathrm{n} 4$, at [173]; $R v$ Williams, above $\mathrm{n} 58$, at [15].

$131 R v$ Shaheed, above $\mathrm{n}$ 126, at [144]. This test was subsequently codified in the Evidence Act 2006, s 30.

132 At [16].

133 At [19].

134 At [21].

135 At [226]. 
subsequent cases indicate that Blanchard J's approach will be followed. For example in Orendowicz $v R$ Allan $\mathrm{J}$ found the surveillance unlawful. ${ }^{136} \mathrm{He}$ then went on to say "this being the case, the search was also unreasonable." ${ }^{137} \mathrm{He}$ stated, citing Blanchard $\mathrm{J}$, that an unlawful search would normally be unreasonable unless the illegality was minor or technical. ${ }^{138}$

In contrast to Blanchard J's approach, Elias CJ argued that an unlawful search is by that very fact unreasonable. She said it could not be reasonable for law enforcement officers to act unlawfully. ${ }^{139}$ This approach is not without support. It was favoured in the dissenting judgment of McKay $\mathrm{J}$ in $R v$ Jefferies, ${ }^{140}$ and is the approach taken in Canada. ${ }^{141}$ Her Honour believed that to hold otherwise would turn the test for whether s 21 was breached into a stand-alone test of the reasonableness of the police conduct irrespective of its illegality. This, she argued, would give the Court the ultimate power to decide the bounds of police conduct rather than assessing reasonableness based on whether the action was within the powers Parliament had granted the police. $^{142}$

The majority decision in Hamed embraces the close relationship between lawfulness and reasonableness which has been favoured since Shaheed. An unlawful search will ordinarily be unreasonable unless it comes within one of the exceptions; that is, if the unlawfulness was only minor or technical. These exceptions acknowledge that it is the test for unreasonableness that Parliament has chosen for compliance with s $21,{ }^{143}$ and they ensure that a finding of a breach of that section has serious implications. ${ }^{144}$

This means that the final proposition in the Bill's explanatory note, at least with respect to trespassory surveillance, was correct: as trespassory surveillance was unlawful, it was likely to be unreasonable unless it was seen as only a minor or technical departure from the lawfulness of the search.

136 Orendowicz $v$ R HC Tauranga CRI-2011-470-000013, 26 September 2011.

137 At [18].

138 At [18].

139 Hamed $v$ R, above n 4, at [50].

$140 R v$ Jefferies [1994] 1 NZLR 290 (CA) at 316.

141 See $R v$ Collins, above n 54, at 278 .

142 Hamed $v$ R, above $\mathrm{n} 4$, at [19] and [50].

143 See Hamed $v R$, above n 4, at [226]. See also $R v N g a n$, above $\mathrm{n} 50$, at [53] per Tipping J.

$144 R v$ Williams, above n 58, at [21]. 


\section{THE IMPACT OF THE VIDEO CAMERA SURVEILLANCE (TEMPORARY MEASURES) ACT 2011}

The final Part of this article will examine in more detail the effect of the Act on the law and its potential impact on the right to be free from unreasonable search and seizure.

\section{A What Was the Effect of the Act on the Lawfulness of Covert Video Surveillance?}

The Temporary Act provided that the use of a video camera as part of, or in connection with a search would not of itself make the search unlawful. With regards to non-trespassory surveillance, this was unnecessary as such surveillance was already lawful at common law. The decision in Hamed did not change this. The definition of "search" in the Act encompasses non-trespassory surveillance "that is a search". ${ }^{145}$ It therefore consolidates the approach taken in Hamed, that there does not need to be physical trespass for a search to occur.

The Act provided that trespassory surveillance was not "of itself" unlawful. The Act was meant to overrule the finding in Hamed that trespassory surveillance was unlawful. However, there is a strong argument that the Act would not have authorised covert video surveillance where a warrant was sought for the sole purpose of undertaking video surveillance. ${ }^{146}$ The Act seems to proceed on the basis that in the case of trespassory video surveillance, the police should state their intention to undertake the surveillance when applying for a warrant. This was what the Court of Appeal in Hunt had recommended ${ }^{147}$ and, according to evidence at the Select Committee hearing, this was the usual practice of the police. ${ }^{148}$ However, the Act did not change the Supreme Court's ruling that s 198 could not authorise an anticipatory warrant, ${ }^{149}$ and the finding that video surveillance was anticipatory in nature. ${ }^{150} \mathrm{~A}$ warrant sought solely for surveillance would therefore be outside the scope of that section. This means that the Act may only have rendered trespassory surveillance lawful where it was undertaken incidentally to a search for "things" believed to be on the premises at the time the warrant was applied for. ${ }^{151}$ This argument is also supported by the wording of the statute itself. The words "as part of" and "in connection with" imply that a search which consists solely of video surveillance is not contemplated by the legislation. While it is unlikely that such searches occur often, this implication strengthens the argument that the act was poorly drafted. Not

\footnotetext{
145 Video Camera Surveillance (Temporary Measures) Act, s 4(b).

146 Samuel Beswick and William Fortherby "Surveilling the Stopgap" [2011] NZLJ 404 at 406.

147 Hunt $v$, above $\mathrm{n} 21$, at [42].

148 Justice and Electoral Committee, above n 1, at 76.

149 Hamed $v R$, above $\mathrm{n} 4$, at [149].

150 At [150].

151 Beswick and Fortherby, above n 146, at [406].
} 
only did it extend unnecessarily to non-trespassory surveillance, it did not cover all instances of trespassory surveillance.

\section{$B$ Did the Act Limit the Right to be Free from Unreasonable Search and Seizure Contained in s 21 of NZBORA?}

The final issue that this article will address is whether the Temporary Act was inconsistent with the right to be free from unreasonable search and seizure. Section 7 of NZBORA requires the Attorney-General to report to Parliament where a Bill appears to be inconsistent with any of the rights and freedoms in the Act. Following official advice, ${ }^{152}$ the Attorney-General did not report on this Bill; that is, he considered it consistent with the right to be free from unreasonable search and seizure. This conclusion was heavily criticised by opposition parties, ${ }^{153}$ as well as several key submitters on the Bill, including the New Zealand Law Society and the Council for Civil Liberties. ${ }^{154}$

\section{The Argument that the Bill was Consistent with s 21: the Official Advice}

The official advice said the Bill was designed to correct a technical deficiency in the law only. All that the Bill did was prevent the Court from finding that a search was unlawful solely because covert video surveillance was used. ${ }^{155}$ Surveillance could still be unlawful because of any other deficiency in the authorisation or execution of the search. Additionally, the Court could still assess surveillance under s 21 and find it unreasonable because, in the circumstances of that case, it was unreasonable to undertake covert video surveillance. ${ }^{156}$ These factors led the advisors to conclude that the Bill did not limit the right to be free from unreasonable search and seizure. ${ }^{157}$

\section{The Alternative Viewpoint}

The contrasting view, that the Bill was inconsistent with s 21 , is based upon the close relationship that the Court has recognised between unlawfulness and unreasonableness. For example the Law Society argued that the concepts of lawfulness and reasonableness are very closely related

152 Public Law Group and the Office of Legal Counsel Video Camera Surveillance (Temporary Measures) Bill (2011): Consistency with the New Zealand Bill of Rights Act 1990 (27 September 2011) at [30].

153 (27 September 2011) 676 NZPD 21454; Video Camera Surveillance (Temporary Measures) Bill 2011 (3332) (select committee report) at 5-9.

154 New Zealand Law Society "Submission to the Justice and Electoral Committee on the Video Camera Surveillance (Temporary Measures) Bill 2011" at 21; New Zealand Council for Civil Liberties "Submission to the Justice and Electoral Committee on the Video Camera Surveillance (Temporary Measures) Bill 2011" at [3]; Justice and Electoral Committee, above n 1, at 31-43.

155 Public Law Group and the Office of Legal Counsel, above n 152, at [18].

156 At [20]-[21].

157 At [30]. 
and cannot be separated into two distinct topics. It argued that by legislating on the issue of the lawfulness of a search, the Bill automatically interfered with the ability of a judge to carry out his or her normal functions under s 21 and took away a whole dimension of the analysis conducted under this section. ${ }^{158}$

As explained above, the Bill did not change the exercise that the judge would be undertaking under s 21 in relation to non-trespassory surveillance. Courts had proceeded on the basis that nontrespassory surveillance was lawful despite the lack of positive authorisation for its use. ${ }^{159}$ In the absence of a warrant regime regulating the deployment of non-trespassory surveillance, there was a lot of room for the Court to assess whether the non-trespassory surveillance, although lawful, was unreasonable because of the circumstances in which it was undertaken. The Temporary Act similarly did not provide any restrictions on the use of non-trespassory surveillance. The legislative history and purpose section of the Act make it clear that the Act was meant to preserve the ability of a judge to assess whether the surveillance was unreasonable. ${ }^{160}$ This means that at common law and under the Act, non-trespassory surveillance was lawful unless the circumstances in which it was conducted rendered it unreasonable. As the legal position was not changed in relation to nontrespassory covert video surveillance, the right to be free from unreasonable search was not affected.

The situation in relation to trespassory surveillance, however, is different. The majority in Hamed found that trepassory surveillance was unlawful because it required positive authority to undertake and there was no statute capable of providing this authorisation. The starting point when assessing the use of trespassory surveillance was the fact that it was unlawful. As an unlawful search, it would be unreasonable unless it came within one of the exceptions, that is, if its use was only a minor or technical departure from legality. ${ }^{161}$ In $R v$ Williams the Court said that what is a minor departure should not be given an expansive meaning. ${ }^{162}$ The Court pointed to the failure to file a report after a warrantless search as an example of a minor breach. ${ }^{163}$ It said that a mistake such as specifying the wrong property in a warrant, or failure of the police to identify themselves if this were a requirement of the statute should not be regarded as minor breaches. ${ }^{164}$ In Hamed itself, Tipping $\mathbf{J}$ found that the surveillance of vehicles on Reid Road was an unlawful search but not unreasonable because there was a low expectation of privacy pertaining to the fact that a driver has

158 Justice and Electoral Select Committee, above n 1, at [31]-[43].

$159 R v$ Gardiner, above $\mathrm{n} 3$, at 136.

160 Video Camera Surveillance (Temporary Measures) Act 2011, s 3(d).

161 Hamed $v$ R, above $\mathrm{n} 4$, at [171].

$162 R v$ Williams, above n 58, at [22].

163 At [22]; $R v$ Smith (James) (1996) 13 CRNZ 481 (CA).

164 At [22]-[23], referring to $R v$ Kappely [2001] 1 NZLR 7 (CA) and $R v$ Te Whatu (2002) 6 HRNZ 673 (CA). 
travelled along a public road. ${ }^{165}$ It is important to remember that Tipping $\mathrm{J}$ took a wider approach to the relationship between unlawfulness and unreasonableness, which was not the majority approach. Further, Tipping J also used a different definition of "search". His judgment contrasts to Blanchard J's judgment in which his Honour held that the surveillance of Reid Road did not amount to a search, because the surveillance only captured images of vehicles moving along the road, about which there was no reasonable expectation of privacy. ${ }^{166}$ Applying the test from Blanchard J's judgment in Hamed, where the only exception to an unlawful search being unreasonable is a minor or technical departure from lawfulness, it is difficult to envisage circumstances in which the deployment of a video camera could be regarded as only a minor or technical departure from legality. ${ }^{167}$ If video surveillance is, because it is prospective in nature, beyond the scope of a warrant, its use can hardly be a minor departure from it, especially when what is a minor departure should be given a restrictive interpretation. The significance of this is that, because it was unlawful and was unlikely to be regarded as only technically unlawful, prior to the Act, trespassory covert video surveillance was likely to always be found to be an unreasonable search.

The Temporary Act provided that the use of covert video surveillance as part of a search authorised under a s 198 warrant would not be unlawful for the sole reason that a camera was employed. ${ }^{168}$ The Act did not amend the s 198 warrant regime. The consequence of this is that the finding in Hamed that such a warrant could not authorise surveillance was not changed by the Act. The long-established position is that, with the exception of an implied licence, officials must have a warrant to enter onto private property. If they do something which is beyond the scope of that warrant then that is unlawful and they are trespassing. ${ }^{169}$ The effect of the Act is to say that despite this, it is lawful to go onto land as authorised by a warrant and overstep the scope of the warrant's authority by undertaking surveillance. Further, the Act did not provide any more judicial oversight for the undertaking of video surveillance. Because a s 198 warrant cannot authorise video surveillance, a judge could not have issued a search warrant but refused to authorise surveillance under it, as the warrant could not authorise the surveillance in the first place. The result of this is that once there are reasonable grounds for issuing a search warrant, undertaking surveillance is prima facie lawful.

As the official advice on the Bill states, the Act preserves the ability of a court to find that, notwithstanding its legality, the use of trespassory surveillance was unreasonable in the particular circumstances. Post-Hamed, a citizen could rely on the fact that trespassory surveillance was not

165 At [224].

166 At [171].

167 Hamed $v$, above $\mathrm{n} 4$, at [224].

168 Section 4(a).

$169 R v$ Jefferies, above n 140, at 313. 
authorised and could be fairly certain this would lead to a finding that its use was unreasonable in breach of NZBORA. However, under the Temporary Act, there would have to be something over and above the fact that trespassory surveillance occurred before a court could find that the search was unreasonable. The Court could not rely on the fact that the police had overstepped the scope of the warrant by undertaking surveillance in order to hold that the search was unreasonable, as under the Act it was not unlawful to do just that. This means that the position of what is a reasonable search was fundamentally changed by the Act. The Act meant that the use of trespassory covert video surveillance was presumptively reasonable, as it was lawful, unless there were additional factors to make its use unreasonable in the particular circumstances.

The Court has said that lawfulness and reasonableness are distinct concepts. However, it is overly simplistic to rely on this to argue that legislation ruling on the lawfulness of a search does not affect the issue of reasonableness, and therefore that, because s 21 concerns reasonableness, it will not be breached by such legislation. Such an argument ignores the Court's approach to these two concepts. In particular it ignores the very limited ability of the Court to assess the reasonableness of a warranted search independently of its lawfulness. The position is that an unlawful search will ordinarily be unreasonable while a search authorised by warrant will not normally be unreasonable. Although the Court has found several exceptions to the proposition that an unlawful search will normally be unreasonable, the nature of trespassory video surveillance makes it very unlikely that its use in conjunction with a s 198 warrant would, prior to the act, have been regarded as falling within these exceptions.

The Act changed the lawful status of covert video surveillance. The Court's approach to the concepts of legality and reasonableness mean that in doing this, it changed the position of what will prima facie be a reasonable search. Further, it did this in a way which makes it lawful, and therefore not in itself unreasonable, for police officers to overstep the scope of a s 198 warrant. This goes against the fundamental legal position that the police must have a warrant to enter onto private property and if they act outside the scope of this warrant, their actions are unlawful ${ }^{170}$ and, unless the unlawfulness was minor, unreasonable. Bearing this in mind, it is not possible to say that the Act was consistent with the right to be free from unreasonable search and seizure.

\section{CONCLUSION}

The Temporary Act was based on the assertion that covert video surveillance had been ruled to be lawful prior to Hamed and that Hamed meant that both trespassory and non-trespassory surveillance were likely to be held unlawful. This article has argued that both of these premises were incorrect. This resulted in the Act applying unnecessarily to non-trespassory surveillance. Further, the Act did not apply to all uses of trespassory surveillance because it did not amend s 198 of the Summary Proceedings Act 1957 and consequently could not authorise a warrant for the sole purpose

$170 R v$ Jefferies, above n 140, at 313. 
of video surveillance. This meant that the Act did not adequately fulfil the purpose for which it was enacted. The Temporary Act was inconsistent with the fundamental common law rules restricting police entry onto private property. It provided that it was not unlawful for the police to undertake surveillance pursuant to a warrant which was not capable of authorising such activity. Finally, the Act was inconsistent with the right to be free from unreasonable search and seizure guaranteed in $\mathrm{s}$ 21 of NZBORA. The argument put forward in favour of the Temporary Act was that it was a legally insignificant but important temporary measure. This article has shown that this was not the case. Rather, the Act disregarded the established common law position concerning police entry onto private property and limited a fundamental right.

The Temporary Act was an example of rushed and poorly-drafted legislation. While it can be accepted that covert video surveillance is an important tool that the police need to be able to use, providing authority for its use was not the only issue at stake. The major flaws in the Act show how important it is for the Crown to step back and undertake a thorough exploration of the law and the implications of any potential action instead of reactively legislating in the face of an adverse court ruling. In the absence of any such consideration, the Act set a dangerous precedent for ill-considered legislative action disguised as a harmless restatement of previous law. 